\title{
Growth and yield components of Wheat varieties as affected by dual purpose practices
}

\author{
Muhammad Islam ${ }^{1 *}$, Shazma Anwar ${ }^{1}$, Saqib Bashir ${ }^{1}$, Wajid Ali Khattak ${ }^{1}$, \\ $\operatorname{Imran}^{1}$, Murad $\mathrm{Ali}^{2}$ and Nadar Khan ${ }^{3}$ \\ 1. Department of Agronomy, The University of Agriculture, Peshawar-Pakistan \\ 2. Department of Plant Pathology, The University of Agriculture, Peshawar-Pakistan \\ 3. Department of Animal Nutrition, The University of Agriculture, Peshawar-Pakistan \\ *Corresponding author's e-mail: islamswati439@yahoo.com
}

Citation

Muhammad Islam, Shazma Anwar, Saqib Bashir, Wajid Ali Khattak, Imran, Murad Ali and Nadar Khan. Growth and yield components of Wheat varieties as affected by dual purpose practices. Pure and Applied Biology. Vol. 4, Issue 4, 2015, pp 491-496. http://dx.doi.org/10.19045/bspab.2015.44006

Received: 04/06/2015

Revised: 06/11/2015

Accepted: $15 / 11 / 2015$

\section{Abstract}

Quality forage availability in winter is a serious problem all over the world. The basic demand of quality food and feed for increasing human and livestock population can be met from the same field by growing wheat for both forage and grain purpose providing perfect management practices. A field experiment was designed in a randomized complete block design during winter 2011-12 to study growth and yield components of wheat varieties as affected by dual purpose practices. Two wheat varieties (Siran-2010 \& Atta-Habib) and dual purpose practice (cutting, grazing and control) were tested in the experiment. Grazing and cutting was done by goats and sickles 70 days after sowing in respective plots. Results evaluated that maximum spikes $\mathrm{m}^{-2}$ (350), grains spike ${ }^{-1}(51.0)$ and thousand grains weight (38.87 g) was produced by Siran-2010. Less days to anthesis (139) and maturity (165) and tallest plants $(98 \mathrm{~cm})$ were maintained by Atta-Habib. No cut plots resulted in highest spikes $\mathrm{m}^{-2}$ (388), grains spike ${ }^{-1}$ (53.2), plant height $(101 \mathrm{~cm})$ and thousand grains weight $(39.43 \mathrm{~g})$. While delayed anthesis (140 days) and physiological maturity (167 days) was observed in cut and grazed plots.

Key words: Wheat; Varieties; Dual purpose practices; Growth and yield components.

\section{Introduction}

Wheat (Triticum aestivum L.) belongs to family Poaceae. Among grain crops it ranks first in the whole world. Wheat green forage in winter season usually contains more crude protein concentration (30\%) for livestock intake, therefore can be successfully grown as a dual purpose crop [1]. In order to overcome the demand of food and feed wheat can be for both forage and grains from the same land under perfect management practices [2,3]. Dual purpose wheat cropping is a distinctive system to sustain valuable forage and grain yield from the same piece of land. Wheat crop minimizes competition among green forage and grain yield [4]. Wheat is also grown for winter grazing purpose to decrease winter supplement costs. Generally wheat is sown 2-3 weeks earlier than the recommended date if it is to be grazed. Grazing can begin six to eight weeks after sowing when the 
crop is 4-6 inches tall. Excessive top vegetative portions that are removed by grazing help to conserve soil moisture by decreasing transpiration rate. This practice is beneficial when rain fall or spring moisture is limited. Russian aphids of wheat can also be controlled by grazing winter wheat [5]. Number of animals carried to the field for grazing depends upon the quantity of forage in the desired area [6]. There are different varieties of wheat, which are selected on number of characteristics such as disease resistance, seed quality, head type, vigorous growth and spike length etc. but no variety contains all the required characteristics and demands to balance numerous risk factors. Cultivar selection for quality green forage and grain yield could provide additional way to meet daily needs of livestock without effecting grain yield in the area. Wheat cultivars have been chosen traditionally on the basis of data obtained from small, ungrazed field plots. The basic prerequisites in cultivar selection are disease resistance, lodging, grain yield and other grain related production attributes. But it has been shown recently that wheat varieties also varied slightly for green forage and grain yield [7]. Selection of desirable varieties is an important economic and management decision for a specific locality $[3,8]$.

\section{Materials and Methods}

A field experiment was carried out at New Developmental Farm, The University of Agriculture, Peshawar, Pakistan during winter season 2011-12. The aim of the experiment was to study growth and yield components of wheat varieties as affected by dual purpose practices. The site is located at ( $\left.34^{\circ} 00^{\prime} \mathrm{N}, 71^{\circ} 30^{\prime} \mathrm{E}, 510 \mathrm{MASL}\right)$. The soil of experimental site has $\mathrm{pH}$ of 8.2 , lime $19 \%$, organic mater $1.50 \mathrm{~g} \mathrm{~kg}^{-1}$, Total nitrogen $4.25 \mathrm{~g} \mathrm{~kg}^{-1}$, Texture class; silty clay loam, Clay $40.2 \%$, Silt 51.1\%, Sand 8.7\%, EC $0.7 \mathrm{ds} \mathrm{cm}^{-1}$, (\%) Bulk Density $1.43 \mathrm{Mg}$ $\mathrm{m}^{-3}$ and Porosity $45.95 \%$.
Two varieties (Siran-2010 \& Atta-Habib) and dual purpose practices (no cut, cutting \& grazing) were tested in the experiment. Seeds were sown with hand drill at the rate of $120 \mathrm{~kg} \mathrm{ha}^{-1}$. Nitrogen was applied at the rate of $140 \mathrm{~kg} \mathrm{ha} \mathrm{ha}^{-1}$, more than the recommended rate $\left(120 \mathrm{~kg} \mathrm{ha}^{-1}\right)$ to recover the vegetative growth after cutting and grazing and phosphorus was applied at the rate of $60 \mathrm{~kg} \mathrm{ha}^{-1}$. After 30 days of sowing half dose of nitrogen was applied with first irrigation, whereas the remaining half was applied at 70 days after sowing (after cutting and grazing). Grazing and cutting was done after 70 days of sowing in respective plots. Cutting was done manually with the help of sickle about 2 to $4 \mathrm{~cm}$ from the ground surface, to make sure that first node of the stem was not affected. Goats were used for grazing purpose. All other agronomic practices were kept constant. Parameters recorded during the course of study were days to anthesis, spikes $\mathrm{m}^{-2}$, grains spike ${ }^{-1}$, days to physiological maturity, plant height $(\mathrm{cm})$ and thousand grains weight $(\mathrm{g})$. Data regarding days to anthesis in each sub plot was measured by counting days from sowing to date when $70-80 \%$ plants reached to anthesis phase. Spikes were counted in four central rows of each sub plot and then changed into spikes $\mathrm{m}^{-2}$ accordingly. For measuring data on grains spike ${ }^{-1}$ ten spikes were selected randomly in each sub plot, threshed separately and number of grains of each spikes was counted and averaged. Data regarding days to physiological maturity in each sub plot was measured by counting days from sowing date to the date when 70 to $80 \%$ plants become physiological mature. Plant height was calculated by measuring height of ten randomly selected plants from the base of plant to the tip of spike in each sub plot and averaged. Thousand grains weight was recorded by weighing thousand grains randomly taken from grain lot of each sup plot. Methods relevant to randomized 
complete block design (split-plot arrangement) were used for statistical analysis of the recorded data. For mean comparison in case of significant difference least significant difference (LSD) test at 5\% level of significance was used [9].

\section{Results and Discussion Days to anthesis}

It was revealed from statistical analysis of the data that varieties, dual purpose practices and V $\mathrm{x}$ DP significantly affected days to anthesis (Table 1). More days to anthesis (140) were taken by Siran-2010 as compared to Atta-Habib which took (139) days to reach to anthesis stage. Days to different phonological stages in wheat varies from cultivar to cultivar due to their genotypic variation [10]. Dual purpose practices (cutting and grazing) delayed anthesis of wheat varieties as compared to no cut plots. Less days to anthesis (138) were taken by wheat crop in no cut plots while cut and grazed plots took more (140) days to reach anthesis stage. The results are also in line with the findings of [2] who observed that cutting at stem elongation stage delayed days to phonological stages. Similarly, [11] found delayed anthesis due to removal of the main stem by grazing. Un-grazed wheat plants reached to anthesis stage earlier than grazed wheat [12]. Interactive effect of varieties and dual purpose practices was significant. Both varieties showed delayed anthesis in cut and grazed plots, while earlier anthesis was observed in control (no cut) plots.

\section{Days to physiological maturity}

Table 1 shows data regarding days to physiological maturity of wheat as affected by varieties and dual purpose practices. Statistical analysis of the data indicated that there were significant variation in days to physiological maturity due to varieties and dual purpose practices, whereas the interaction of varieties and dual purpose practices was found non-significant. Wheat variety Siran-2010 took more days (166) to physiological mature as compared to AttaHabib [3]. These results are in accordance with [13] who noticed that days to maturity of wheat varied due to genotype. Days to maturity of wheat were enhanced by dual purpose practices. Delayed maturity was observed in grazed and cut plots $(166 \& 167$ days) respectively while plants in no cut plots matured earlier (163 days). The results are in line with the findings of [12] who reported that grazed wheat ripened later than un-grazed wheat.

Table 1. Days to anthesis, days to physiological maturity and plant height of wheat varieties as affected by dual purpose practices.

\begin{tabular}{|c|c|c|c|}
\hline Effects & Days to anthesis & $\begin{array}{c}\text { Days physiological } \\
\text { maturity }\end{array}$ & Plant height (cm) \\
\hline \multicolumn{4}{|l|}{ Dual purpose practices (DP) } \\
\hline No cut & $138 \mathrm{~b}$ & $163 \mathrm{~b}$ & $101 \mathrm{a}$ \\
\hline Cut & $140 \mathrm{a}$ & $167 \mathrm{a}$ & $93 \mathrm{c}$ \\
\hline Grazed & $140 \mathrm{a}$ & $166 \mathrm{a}$ & $96 \mathrm{~b}$ \\
\hline LAD value & 0.51 & 1.04 & 1.38 \\
\hline \multicolumn{4}{|l|}{ Varieties $(\mathbf{V})$} \\
\hline Siran-2010 & $140 \mathrm{a}$ & $166 \mathrm{a}$ & $96 \mathrm{~b}$ \\
\hline Atta-Habib & $139 \mathrm{~b}$ & $165 \mathrm{~b}$ & $98 \mathrm{a}$ \\
\hline LSD value & 0.4 & 0.85 & 1.13 \\
\hline \multicolumn{4}{|l|}{ LSD values for interaction } \\
\hline DP x V & * & NS & NS \\
\hline
\end{tabular}




\section{Plant height (cm)}

Wheat varieties varied significantly for plant height (Table 1). Taller $(98 \mathrm{~cm})$ plants were maintained by Atta-Habib as compared to Siran-2010 $(96 \mathrm{~cm})$. Significant differences in plant height among wheat varieties were reported by many scientists due to genetic variation [13, 14]. Plant height was considerably reduced by dual purpose practices. Taller plants $(101 \mathrm{~cm})$ were recorded in no cut plots as compared to cut and grazed plots. Due to shorter growth period in cut and grazed plots new shoots could not attain the same plant height as of plants in no cut plots. These results are in line with [15] who found that continuous grazing by rabbits reduced plant height. Similarly [16] observed longest plants in no cut plots as compared to cut plots.

\section{Spikes $\mathbf{~ m}^{-2}$}

Statistical analysis of the data showed considerable effect of wheat varieties and dual purpose practices on spikes $\mathrm{m}^{-2}$ (Table 2). Wheat variety Siran-2010 produced more (350) spikes $\mathrm{m}^{-2}$. Varietal genetic differences and its interaction to environment are responsible for significant variation in spikes $\mathrm{m}^{-2}$ of wheat cultivars $[17,18,19]$. Plots that receive no cut treatment resulted in highest (388) spikes $\mathrm{m}^{-2}$ while cut plots produced minimum (321) spikes $\mathrm{m}^{-2}$. Reduction in spikes $\mathrm{m}^{-2}$ in cut and grazed plots might be due to the fact that these treatments were applied at the time of stem elongation stage, because of which plants remained unable to produce any more tillers or even develop the already produced tillers. Our results are in agreement with the investigations of [1] who reported that no cut plots produced more spikes per unit area than cut plots.

\section{Grains spike $^{-1}$}

Table 2 shows that wheat varieties and dual purpose practices considerably affected grains spike $^{-1}$. Siran-2010 produced higher (51.0) number of grains spike ${ }^{-1}$. The variation in number of grains spike ${ }^{-1}$ between varieties might be due to genetic variation. These results are in agreement with the findings of [20] who found variations among wheat varieties for number of grains spike ${ }^{-1}$. Dual purpose practices significantly reduced number of grains spike $^{-1}$ of wheat. More (53.2) grains spike ${ }^{-1}$ were produced by plants in no cut plots while lesser (47.5) grains spike

${ }^{1}$ were produced by plants in cut plots. The reduction in grains spike ${ }^{-1}$ might be due to strain induced by cutting and grazing during the vegetative stage of crop, which had removed the initially accumulated nutrients with green forage and shorten growth required for maximum economic yield production. These results are in agreement with the findings of [16] who reported less number of grains spike ${ }^{-1}$ in grazed plots than un-grazed plots. Our results are further supported by [2] who found that grains spike ${ }^{-1}$ significantly reduced in cut plots as compared to control.

\section{Thousand grains weight $(\mathrm{g})$}

It was revealed from data analysis that varieties and dual purpose practices significantly affected thousand grains weight of wheat (Table 2). Grains weight is a major contribution to final yield. Grains of variety Siran-2010 attained maximum weight (38.87 g) than Atta-Habib (38.17 g). The same results were found by $[13,21]$ who reported significant variations among wheat varieties for yield characters. Dual purpose practices considerably reduced thousand grains weight. Heavier grains $(39.43 \mathrm{~g})$ were maintained by plants in no cut plots than cut and grazed plots. Decapitation stress reduced thousand grains weight. $[2,13,22,23]$ also found decrease in thousand grains weight of wheat when all or two top leaves were detached after 100 days of sowing. 
Table 2. Spikes $\mathrm{m}^{-2}$, grains spike ${ }^{-1}$ and thousand grains weight (g) of wheat varieties as affected by dual purpose practices.

\begin{tabular}{|c|c|c|c|}
\hline Effects & Spikes $\mathbf{~ m}^{-2}$ & Grain spike $^{-1}$ & Thousand Grains weight (g) \\
\hline \multicolumn{4}{|l|}{ Dual purpose practices (DP) } \\
\hline No cut & $388 \mathrm{a}$ & $53.2 \mathrm{a}$ & $39.43 \mathrm{a}$ \\
\hline Cut & $321 \mathrm{c}$ & $47.5 \mathrm{c}$ & $37.38 \mathrm{c}$ \\
\hline Grazed & $329 \mathrm{~b}$ & $49.0 \mathrm{~b}$ & $38.75 \mathrm{~b}$ \\
\hline LAD value & 6.55 & 1.37 & 0.57 \\
\hline \multicolumn{4}{|l|}{ Varieties (V) } \\
\hline Siran-2010 & $350 \mathrm{a}$ & $51.0 \mathrm{a}$ & $38.87 \mathrm{a}$ \\
\hline Atta-Habib & $342 \mathrm{~b}$ & $48.9 \mathrm{~b}$ & $38.17 \mathrm{~b}$ \\
\hline LSD value & 5.35 & 1.12 & 0.47 \\
\hline $\begin{array}{l}\text { LSD values for interaction } \\
\text { DP } x \text { V }\end{array}$ & NS & NS & NS \\
\hline
\end{tabular}

Means with different letters differ significantly according to Least Significant Difference (LSD) test $(P<0.05)$. NS stands for non-significant difference, and ${ }^{*}$ at $P<0.05$ level, respectively.

\section{Conclusion}

It is concluded from the results of this experiment that variety Siran-2010 performed better as compared to Atta-Habib in terms of yield components. Although cutting and grazing after 70 days of sowing reduced grain yield of wheat but gave additional benefits in terms of fodder and forage for livestock.

\section{Authors' contributions}

Conceived and designed the experiments: $S$ Anwar \& M Islam. Performed the experiments: M Islam. Data collection and field inspections: M Islam, S Bashir, WA Khattak \& Imran. Statistical analysis of data: $M$ Islam, $M$ Ali \& $\mathrm{N}$ Khan. Contributed reagents/materials/analysis tools: N Khan \& M Ali. Arrangement of goats for grazing: $\mathrm{N}$ Khan. Wrote the paper: M Islam \& S Anwar.

\section{References}

1. Arif M, Khan MA, Akbar H, Sajjad \& Ali $S$ (2006). Prospects of wheat as a dual purpose crop and its impact on weeds. Pak J. Weed Sci. Res. 12(1-2): 13-17.

2. Khalil SK, Khan F, Rehman A, Muhammad F, Amanullah, Khan AZ, Shah MK \& Khan H (2011). Dual purpose wheat for forage and grain yield in response to cutting, seed rate and nitrogen. Pak. J. Bot. 43(2): 937947.

3. Imran, Khan AA, Zada H, Ahmad F \& Ullah I (2015). Grain yield and yield components of wheat cultivar Siran2010 as affected by phosphorus level under rainfed condition. J. N. Sci. Res. 5: (5) 139-143.

4. Anonymous (2006). Govt. Pakistan, Ministry of food, agriculture and livestock. Econ. Wing, Islamabad, 1819.

5. Holman TL, Loyn DJ \& Luebbe MK (2010). Grazing winter wheat in Nebraska.

6. Epplin FM, Hossain I \& Krenzer EG (2000). Winter wheat fall winter forage yield and grain yield response to planting date in dual purpose system. Agric. System 63: 161-173.

7. Horn G, Krenzer G, Bernado D \& Ddniel BM (1994). Preliminary evaluation of wheat varieties in the wheat grain/stocker enterprise. Animal Sci. Res. Report.151-157. 
8. Morgan G, Been \& Brent (2007). Wheat variety selection is critical for grazing and grain. Southwest Farm Press.34: 10.

9. Steel RGD \& Torrie JH (1984). Principles and procedure of statistics $2^{\text {nd }} \mathrm{ed}$. Mc, Graw Hill, New York.

10. Bakht J, Shafi M, Zubair M, Khan MA \& Shah Z (2010). Effect of foliar vs soil application of nitrogen on yield and yield components of wheat varieties. Pak. J. Bot. 42(4): 2737-2745.

11. Miyan S \& Clune S (2008). Effect of grazing on wheat grain yield and quality in Western Australia. Proceedings of 14th Agro. Conf. 2008, 21-25 Sept. 2008, Adelaide, South Australia.

12. Summers RW (1990). The effect of winter wheat grazing by Brent geese Brantabernicla. J. Appl. Ecol. 27(3): 821-833.

13. Munsif F \& Arif M (2011). Effect of planting dates on the potential use of dual purpose wheat cultivars. Ph.D. Thesis. KPK Agric. Uni. Peshawar.

14. Shahzad K, Bakht J, Shah WA, Shafi M \& Jabeen N (2002). Yield and yield components of various wheat cultivars as affected by different sowing dates. Asian J. Pl. Sci. (5): 522-525.

15. Crawley MTJ \& Weiner J (1991). Plant size variation and vertebrate herbivore: Winter wheat grazed by rabbits. J. Appl. Ecol. 28(1): 154-172.

16. Noy-Meir I \& Briske DD (2002). Response of wild wheat populations to grazing in Mediterranean grassland: the relative influence of defoliation, competition, mulch and genotype. J. Appl. Ecol. 39(2): 259-278.
17. Aslam M, Hussain M, Akhtar M, Cheema MS\& Ali L (2003). Response of wheat varieties to sowing dates. Pak. J. Agron. 2: 190-194.

18. Khaliq I, Paveen N \& Chowdhry MA (2004). Correlation and path coefficient analysis in bread wheat. Int. J. Agric. Biol. 6(4): 633-635.

19. Shah WA, Bakht J, Ullah T, Khan AW, Zubir M \& Khakwani AA (2006). Effect of sowing dates on yield and yield components of different wheat varieties. J Agron. 5(1): 106-110.

20. Haider RS (2004). Growth and yield response of three wheat varieties to $\mathrm{N}$ alone and spring in combination with $\mathrm{P}$ and $\mathrm{P}+\mathrm{K}$ under late sown conditions. $\mathrm{M}$. Sc. (Hons) Thesis, University of Agriculture, Faisalabad, Pakistan.

21. Al-Doss AA, Al-Hazmi AS, Dawabah AAM, Abdel-Mawgood AA, AlRehiayani SM, Al-Otayk S, Mousatafa KA \& Motawei MI (2010). Impact of Cre and peroxide genes of selected new wheat lines on cereal cyst nematode (Heteroderaavenaewoll) Aust. J. Crop Sci. 4(9):737-743.

22. Shuja MN, Dure-Nayab, Ali M, Iqbal A \& Khalil IH (2010). Evaluating the response of wheat genotypes to forage clipping. Int. J. Agric. Biol. 12(1): 111114.

23. Hulmel MB, Heumez E, Pluchard P, Beghin D, Departureaux C, Giraud A \& Gouis JL (2005). Indirect versus direct selection of winter wheat for low-input or high-input levels. Crop Sci. Soci. America. 45: 1427-1431. 